\title{
A atuação pastoral das irmandades no Centro do Rio de Janeiro: séculos XIX e XX
}

\author{
Orientador: Prof. Abimar Oliveira de Moraes \\ Pesquisadora: Geysa Pereira de Magalhães \\ Fonte: $\mathrm{CNPq}$
}

\section{Introdução}

A pesquisa, nessa segunda fase, tem por objeto de estudo a atuação pastoral das Irmandades católicas no Centro do Rio de Janeiro, nos séculos XIX e XX. As Irmandades foram responsáveis pela reunião fraterna de homens e mulheres, pelo desenvolvimento da religiosidade popular, por diversos serviços de caráter sócio-caritativo, desempenhando um papel relevante na construção identidade do catolicismo "carioca".

\section{Objetivos}

Investigar a ação pastoral das Irmandades do Centro do Rio de Janeiro nos séculos XIX e XX, a fim de compreender o processo histórico e evolutivo pastoral delas, bem como, o seu papel na construção da identidade do catolicismo na Cidade do Rio de Janeiro. Por fim, buscar integrar os resultados desta pesquisa com os da pesquisa precedente sobre os séculos XVII e XVIII. 